\title{
The Multiple Integration and Systemic Establishment of Fine Arts in Preschool Education
}

\author{
Lijuan Feng \\ Feixian Campus \\ Linyi University \\ Linyi, China 273400
}

\begin{abstract}
Fine arts of Preschool Education is a comprehensive course aiming at cultivating students' artistic quality and preschool education professional abilities, it has characteristics of distinct diversity, integration, interdisciplinary integration. Its course design shall be based on Preschool Education and social needs, with the existing course resources optimized, it needs to intensify the internal connection and multiple integration between internal factors of fine arts, fine arts and relevant courses, as well as relevant fields, promote the rational establishment of knowledge abilities and orderly connection between teaching modules so as to achieve the organic integration of class teaching and preschool education goals.
\end{abstract}

Keywords-preschool education; fine arts; multiple integration; systemic establishment

\section{INTRODUCTION}

Fine arts of Preschool Education is a main course of teacher education in colleges, it takes the mission to improve students' aesthetic abilities, preschool education skills, cultivate students' abilities of artistic practice and innovation, which play an important role in improving students' professional development and comprehensive quality. Nowadays, restricted by the development history of domestic preschool education and faculties, the construction of fine arts of Preschool Education in colleges are falling behind, whose course system and teaching contents go off the needs of preschool education career, simple teaching goal, outdated teaching modes and methods are still not changed, so it is difficult to meet the needs to improve the preschool education. The situation has not only severely restricted the construction of courses for Preschool Education and the implementation of fine arts teaching but also do bad to the improvement of students' comprehensive quality and preschool education capabilities as well as the coming employment and sustainable development. Based on the development and needs of preschool education, characteristics of fine arts, as well the integration of existing course resources, this article re-develop and design wholly a new fine arts system which has rational systematic structure, multiple educational goals as well as well going teaching practice.

\section{MultiPle INTEGRATION OF Fine ARts RESOURCES FOR PRESCHOOL EDUCATION}

Fine arts of Preschool Education covers serial course elements such as drawing, handwork, design, appreciation, children aesthetic education practice and so on, which own all kinds of contents and forms, rich humanistic connotations as well as characteristics of distinct diversity, integration, interdisciplinary integration and so, playing an indispensable role in the professional development and improvement of comprehensive quality of preschool educators. Considering the situation where existing fine arts courses of Preschool Education are loose and course modules are isolated, college teachers shall start from the course integration and diversity to set a concept of big fine arts course, integrating all course resources such as professional drawing, handwork, children fine arts education practice and so on, widely absorbing internationally advanced techniques and educational philosophies so as to achieve the multiple integration and integrated design of fine arts courses.

\section{A. Multiple Integration of Course Structures}

According to the actual needs of preschool education, we shall integrate the existing fine arts course structure centered on students' artistic ability, improvement of comprehensive quality and the needs of professional development: Rationally establish a course structure mode where subject-based teaching is combined with comprehensive course development, and well treat the structure relations between basic courses, comprehensive courses and practical courses; Establish module-based and layered progressive course structure, intensifying the rational establishment and efficient connection between different subject contents; Intensify practical courses, develop applied and module-based courses such as artistic creation and exchange, social service, children educational practice and so on, achieving the multiple integration of course knowledge, abilities and education of emotion and values, so as to improve students' abilities of practice and innovation.

\section{B. Multiple Integration of Teaching Contents}

Break through the boundaries of traditional subjects and promote the multiple integration and intersectional penetration of teaching contents. Fine arts of Preschool Education have common characteristics such as aesthetics, joyfulness and innovation, who teaching contents and artistic forms are closely related and cannot be divided. The multiple integration of fine arts of Preschool Education should begin with characteristics of Preschool Education and course design, showing the cross integration and penetration between different subject contents and artistic forms, for example, add relevant 
appreciation factors during the drawing teaching, add design factors in the manual teaching, instead of simple teaching and skill training of course theories. Furthermore fine arts design of Preschool Education shall stress of order, advancement and operability of teaching contents, further clarify the internal connection and orderly connection between relevant course modules, widely absorb internationally advanced fine arts techniques and education concept, add social practice and children education professional knowledge and promote the innovation of teaching contents.

\section{Multiple Integration of Teaching Methods}

According to features of fine arts courses of Preschool Education, introduce new teaching modes and methods such as works appreciation, cooperative creation, social service and children education practice, create a three-dimensional and dynamic open class, encourage students to question fearlessly and dare explore difficulties in learning, fully stir students' initiatives and creativities in learning, stimulate creative thought and practice innovation, adopt online teaching, after class instruction and so on, provide students with abundance after class resources for learning, further expand teaching space, enrich teaching forms and improve the teaching quality of fine arts of Preschool Education in all aspects.

\section{DESIGN AND CONSTRUCTION OF FINE ARTS COURSE OF PRESCHOOL EDUCATION}

According to features of Preschool School and students' needs for development, optimize and integrate the existing fine arts course system from macroscopic, middle and microscopic layers, delete some outdated and repeated courses, add humanities education, professional education and social practice courses, stress the internal connection and orderly connection between course modules, build a new fine arts system of Preschool Education featuring rational structure, multiple educational goals and applicable for teaching and practice.

\section{A. Macroscopic Layer}

Consider the talent cultivation goals of preschool education, build a " $2.5+1+0.5$ " mode: of which, the first two years and a half are designed for professional basic courses, and the teaching mainly includes drawing, handwork, appreciation, design, fine arts at kindergartens, aiming to solidify students' basic knowledge and professional skills of fine arts; the following year is designed for improvement of comprehensive quality of fine arts, through learning and training of fine arts courses, students will have their comprehensive quality and practice abilities improved; the last half a year is designed for cultivation of professional skills, through the children education practice, students will have their educational skills trained, and knowledge is converted and applied in practices of fine arts education. Based on the overall design of fine arts as above, we can achieve rational setting and efficient implementation of fine arts courses at different grades and stages so as to further enrich and improve the course systems and upgrade students' comprehensive quality and abilities of children education.

\section{B. Middle Layer}

According to features of Preschool School, optimize and integrate the existing course factors such as drawing, handwork, design and appreciation, deeply discuss the integration and internal relations between relevant courses, based on which, through artistic edition, theme education design and so on, combine the above mentioned existing course factors with social service, self quality improvement as well as children education practice, develop preschool education Fine Arts Comprehensive Courses and textbooks; rationally arrange fine arts theory, skill training and social practice, and build a fine arts comprehensive system integrating artistic perception, aesthetic experience, skill training as well as innovation application.

\section{Microscopic Layer}

Based on the subject teaching, rationally build a new fine arts system of preschool education which integrates professional theory, skill training, after school practice and teaching quality monitoring: Stress the footstone of theory courses on cultivating professional quality, create a theory course system under the framework "History of Fine Arts, appreciation, professional theories"; aim at skill training, aesthetics and innovative ability, build a new skill course with complete system and meeting students' cognitive rules. Stress practical application courses, build a practical course system with combination of social practice and fine arts creation, practice and training, instruct students to combine the knowledge and skills that they have leaned with children aesthetic education and social practice so as to improve students' professional skills and social service abilities. Establish a three-level teaching quality guarantee and monitoring system including school, teaching department and teaching research office, regularly hold teacher-student discussion, student review, peer review and expert review and so on, reflect teaching defects impersonally and in time. Set up a professional teacher teaching information database, trace, check and review the teaching course and results so as to advance the teaching quality.

\section{Design of Fine Arts Course of Preschool Education}

According to the talent cultivation goals of preschool education, systematically describe the nature, value, design concept and teaching rules of fine arts of Preschool Education, rationally plan and design the course structure, teaching contents, class hours, teaching modes and methods, tests and reviews so as to form a systematic and complete course structure system and teaching methods, design and draft Fine Arts Plan of Preschool Education and apply at University L X Campus and educational institutes.

\section{CONCLUSION}

Fine Arts of Preschool Education is required for Preschool Education, which is an important way to improve students' artistic quality, children education skill, foster perfect personality, promote students' health development in all aspects. The course system reform and teaching mode innovation play an important role in promoting the construction of preschool education, improving the quality of talent 
cultivation of preschool education and boosting the development of basic education.

Fine Arts course of Preschool Education covers course elements such as drawing, handwork, design and appreciation, having features of divers contents and forms, rich meaning of humanities, as well as features multiple, integrated and interdisciplinary, and it plays an indispensable in the professional development and improving comprehensive quality of children education teachers.

Considering that Fine Arts course of Preschool Education has a loose system, single teaching goal, separation of teaching contents from the needs of children teaching, college teachers and management should start with the course integration and diversity, integrate course resources such as drawing, handwork, appreciation, children fine arts education practice of preschool education, widely absorb internationally advanced techniques and educational concepts so as to achieve the multielement integration and integrated design of fine arts course.

\section{REFERENCES}

[1] Tang Zhi, Status Quo and Reform Development Researches of Fine Arts Teaching in Colleges - based on Preschool Education, Master's Paper of Hunan Normal University, 2006.

[2] Chen Gao, Reform, Practice and Exploration of Fine Arts Course of Preschool Education, Success. Education, 2011.1.

[3] Li Qun, Construction of Fine Arts Course of Preschool Education on the Background of Internet, Journal of South China Normal University (Social Science Edition), 2002.4.

[4] Chen Bolan, Discussion on Problems of Applying Fine Arts Course of Preschool Education, Survey of Education, 2014.7.

[5] Li Lihua, Xu Hongmei, Researches on Integration of Fine Arts Course Structure of Preschool Education in Colleges, Heilongjiang Researches on Higher Education, 2013.9. 